\title{
HUBUNGAN ANTARA TINGKAT PENGETAHUAN TENTANG KANKER SERVIKS DENGAN MOTIVASI MELAKUKAN PEMERIKSAAN PAP SMEAR PADA IBU RUMAH TANGGA DI DESA GULUNAN SIDOKERTO KECAMATAN PLUPUH KABUPATEN SRAGEN
}

\author{
Oleh : \\ Rahayu Setyaningsih ${ }^{1}$ Endang Dwi Ningsih ${ }^{2}$ Bagus Permadi $^{3}$
}

\begin{abstract}
Background The interviews with housewives in the village Gulunan Sidokerto, most say not to know about cervical cancer and the dangers, so that people's motivation for the early detection of cervical cancer is also lower than all the proven mother in the village has never been anyone doing a Pap test.

The purpose of this study was to determine the relationship between the level of knowledge about cervical cancer with a Pap smear examination motivation housewives in the village of Subdistrict Plupuh Gulunan Sidokerto Sragen.

Subjects were mothers of the population in the village of 45 people Gulunan Sidokerto number by looking at the table Krecji, samples found as many as 40 people. This research is analytic, the research design and approach of cross sectional correlation. The sampling technique used is nonpropability sampling is purposive sampling .

Data analyzed by chi-square test with $p=0.05$, obtained $p$ value of 0.004 to $p$ $<0.05$, which means that $\mathrm{Ho}$ is rejected and $\mathrm{Ha}$ accepted .

The conclusion of the study. There is a relationship between the level of knowledge of cervical cancer with the Pap smear examination motivation housewives in the village of Subdistrict Plupuh Gulunan Sidokerto Sragen with $\mathrm{p}=0.004$.
\end{abstract}

Keywords : Knowledge Level, Cervical Cancer, Motivation, Pap Smear .

\section{PENDAHULUAN}

Kanker leher rahim adalah kanker yang terjadi pada serviks uterus, kanker ini biasa terjadi pada wanita berusia di atas 35 tahun, tetapi kasus ini juga pernah dialami oleh wanita berusia 20-30 tahun. (Nurchasanah, 2009) Di Amerika Serikat, tahun 2005 lalu sekitar 10.370 kasus didiagnosa kanker serviks dan 3.710 diantaranya diperkirakan meninggal. Diperkirakan, hampir 99\% kasus kanker disebabkan infeksi Human Papillomavirus (HPV), berisiko mengalami kanker serviks 50-100 kali lebih besar dibanding yang tidak terinfeksi. Penelitian yang dilakukan beberapa rumah sakit di Indonesia, mendapati kejadian infeksi tipe 16 sebesar $44 \%$, tipe 18 sebesar $39 \%$, dan tipe 52 sebesar 14\%. Sisanya sebesar $14 \%$ terdeteksi infeksi HPV multiple. (Andrijono, 2006) Skrining dengan Pap Smear menurunkan angka kematian akibat kanker serviks di Amerika Serikat sekalipun masih ada sekitar 4000 wanita yang meninggal setiap tahun karena kanker serviks, dan sekitar 15.000 wanita yang didiagnosis kanker serviks yang infasif. Di negaranegara yang berkembang, kanker serviks adalah penyebab utama kematian karena program skrining yang tidak adekuat. (Baradero, 
Dayrit, dan Siswadi, 2007) Diagnosis dapat ditemukan setelah hasil Pap Smear disertai dengan adanya displasia, atau sel-sel atipik persisten yang diikuti dengan hasil biopsi yang mengidentifikasi adanya neoplasma intra-epitel cervikal (CIN) atau lesi intra-epitel skuamosa tingkat tinggi (HGSL). (Mitayani, 2009) Kanker serviks stadium awal bisa didiagnosa dengan melakukan pemeriksaan sitologi melalui Pap Smear pada cairan serviks. (Yatim, 2005) Hampir $50 \%$ penderita kanker serviks ternyata tidak melakukan Pap Smear dalam 10 tahun terakhir. (Yatim, 2005) Studi pendahuluan di Desa Gulunan Sidokerto, Kecamatan Plupuh, Kabupaten Sragen, diperoleh data jumlah ibu sekitar 118 orang. Hasil wawancara dengan ibu rumah tangga, sebagian besar mengatakan tidak tahu tentang kanker serviks dan bahayanya, hal ini menunjukkan bahwa pengetahuan masyarakat tentang kanker serviks masih tergolong rendah, sehingga motivasi masyarakat untuk melakukan deteksi dini kanker serviks juga rendah terbukti dari semua ibu di desa tersebut belum pernah ada yang melakukan pemeriksaan Pap Smear.

\section{METODE PENELITIAN}

Penelitian ini merupakan penelitian analitik dengan desain korelasi dan pendekatan cross sectional untuk mengetahui hubungan antara tingkat pengetahuan sebagai variabel bebas dengan motivasi melakukan pemeriksaan Pap Smear sebagai variabel terikat. Populasi data penelitian ini adalah ibu-ibu di Desa Gulunan Sidokerto, Kecamatan Plupuh, Kabupaten Sragen, yaitu sejumlah 45 ibu rumah tangga sehingga sampelnya sebesar 40 orang berdasarkan tabel krecjie. Teknik sampling adalah nonprobability sampling. Instrumen penelitian yang digunakan adalah kuesioner untuk menilai tingkat pengetahuan tentang kanker serviks sejumlah 20 pertanyaan dan kuesioner untuk menilai motivasi melakukan Pap Smear sejumlah 10 pertanyaan dengan masing-masing jawaban menggunakan skala Guttman.

\section{HASIL PENELITIAN}

Berdasarkan data dari 40 responden didapatkan hasil untuk tingkat pengetahuan sebagai berikut :

Tabel 1. Distribusi Frekuensi Tingkat Pengetahuan Tentang Kanker Serviks

\begin{tabular}{l|c|c}
\hline \multicolumn{1}{c|}{ Tingkat } & $\mathrm{F}$ & Persentase \\
Pengetahuan & 25 & 62,50 \\
\hline Tinggi & 12 & 30 \\
Sedang & 3 & 7,5 \\
Rendah & 40 & 100 \\
\hline Total &
\end{tabular}

Dari tabel di atas dapat dicermati bahwa persentase tingkat pengetahuan responden pada kategori tinggi adalah 62,5\%. Sedangkan untuk kategori rendah hanya $7,5 \%$. Untuk analisa univariat diperoleh mean sebesar 13,80 median 14,50 dan modus 16 .

Tabel 2. Tabel Distribusi Frekuensi Motivasi Melakukan Pap Smear

\begin{tabular}{c|c|c}
\hline Motivasi & F & Persentase \\
\hline Tinggi & 27 & 67,50 \\
Sedang & 13 & 32,50 \\
Rendah & 0 & 0 \\
\hline Total & 40 & 100 \\
\hline
\end{tabular}

Dari tabel di atas didapatkan bahwa motivasi dengan tinggi sebanyak $67,5 \%$ dan kategori sedang untuk motivasi sebanyak $32,5 \%$. Untuk analisa univariat diperoleh mean sebesar 7,73 median 8 serta modus 9 . 
Tabel 3. Tabulasi Silang Hubungan Tingkat Pengetahuan Tentang Kanker Serviks dengan Motivasi Melakukan Pemeriksaan Pap Smear

\begin{tabular}{|l|c|c|c|c|}
\hline \multirow{2}{*}{$\begin{array}{c}\text { Tingkat } \\
\text { Pengetahu }\end{array}$ an } & \multicolumn{2}{|c|}{ Motivasi } & \multicolumn{2}{|c|}{ Total } \\
\cline { 2 - 5 } & sedang & Tinggi & \multicolumn{2}{|c|}{} \\
\cline { 2 - 5 } & $\mathrm{n}$ & $\mathrm{n}$ & $\mathrm{n}$ & $\%$ \\
\hline Tinggi & 4 & 21 & 25 & 62,5 \\
Sedang & 6 & 6 & 12 & 30 \\
Rendah & 3 & 0 & 3 & 7,5 \\
\hline Total & 13 & 27 & 40 & 100 \\
\hline
\end{tabular}

Dari hasil uji Chi-Square dengan $\alpha=5 \%(0,05)$ diperoleh $p$ sebesar 0,004 sehingga dapat ditarik kesimpulan ada hubungan antara tingkat pengetahuan tentang kanker serviks dengan motivasi melakukan pemeriksaan Pap Smear Di Desa Gulunan Sidokerto Kecamatan Plupuh Kabupaten Sragen.

\section{PEMBAHASAN}

Dari hasil tabel 1. didapatkan tingkat pengetahuan responden yang tinggi adalah $62,5 \%$. Sedangkan yang rendah $7,5 \%$. Hal ini menunjukkan bahwa tingkat pengetahuan ibu-ibu tentang kanker serviks di desa tersebut tergolong tinggi. $\mathrm{Hal}$ tersebut dipengaruhi beberapa faktor diantaranya segi pendidikan, media, lingkungan, pengalaman, usia, sosial budaya dan ekonomi. Menurut Erfandi (2009), berikut adalah uraian dari faktor-faktor yang mempengaruhi tingkat pengetahuan seseorang.

Pertama, pendidikan adalah suatu alat yang dapat dipakai untuk memperbaiki dirinya dalam melangsungkan kehidupan bermasyarakat. Tingkat pendidikan seseorang berpengaruh dalam memberikan respon yang berasal dari luar. Orang yang mempunyai pendidikan tinggi akan memberikan respon yang lebih rasional daripada yang pendidikannya rendah atau tidak berpendidikan sama sekali.

Mayoritas ibu-ibu di desa tersebut berpendidikan SMA keatas sehingga pengetahuan mereka tentang kanker serviks juga tinggi, hal ini ditunjukkan dari hasil tingkat pengetahuan ibu yang tinggi diperoleh hasil sebanyak 25 orang $(62,50 \%)$.

Kedua, media informasi yang diperoleh baik dari pendidikan formal maupun non formal dapat memberikan pengaruh jangka pendek sehingga menghasilkan perubahan atau peningkatan pengetahuan. Adanya inovasi atau informasi baru yang muncul dari media dapat memberikan landasan kognitif bagi terbentuknya pengetahuan tentang hal tersebut. Beberapa media sosial, misal: TV, surat kabar, poster yang mengiklankan tentang kesehatan reproduksi wanita. Sehingga ibu-ibu di desa tersebut sedikit demi sedikit memahami untuk menjaga kesehatan reproduksinya.

Ketiga, lingkungan adalah segala sesuatu yang ada di sekitar individu, baik lingkungan fisik, biologis maupun sosial. Lingkungan berpengaruh terhadap proses masuknya pengetahuan ke dalam individu yang berada dalam lingkungan tersebut. Hal ini terjadi karena adanya interaksi timbal balik ataupun tidak yang akan direspon sebagai pengetahuan oleh setiap individu. Semula ada ibu yang tidak mengetahui mengapa perlu memeriksakan kesehatan reproduksinya, karena ibu-ibu lain yang sebelumnya sudah mengetahui tentang pentingnya memeriksakan kesehatan reproduksinya. Hal ini mempengaruhi ibu yang sebelumnya belum mengetahuinya untuk memeriksakan diri ke bidan setempat.

Keempat, pengalaman sebagai sumber pengetahuan adalah suatu cara untuk memperoleh kebenaran pengetahuan dengan cara mengulang kembali pengetahuan yang diperoleh dalam memecahkan ma- 
salah yang dihadapi masa lalu. Sebelumnya ada ibu yang pernah mengalami endometriosis dan akhirnya rahim ibu tersebut dilakukan pengangkatan, sehingga ibu tersebut selalu ingin tahu tentang kesehatan reproduksi dengan selalu konsultasi pada bidan.

Kelima, usia juga mempengaruhi terhadap daya tangkap dan pola pikir seseorang. Semakin bertambah usia semakin berkembang pula daya tangkap dan pola pikirnya, sehingga pengetahuan yang diperoleh semakin baik. Pada usia madya, individu akan lebih berperan aktif dalam masyarakat dan kehidupan sosialnya seperti banyak menggunakan waktunya untuk membaca, sehingga pengetahuannya dapat bertambah.

Keenam, kebiasaan dan tradisi yang dilakukan orang-orang tanpa melalui penalaran apakah yang dilakukan itu baik atau buruk. Dengan demikian seseorang akan bertambah pengetahuannya walaupun tidak melakukan. Status ekonomi seseorang juga dapat mempengaruhi pengetahuan karena adanya fasilitas yang dibutuhkan untuk kegiatan tertentu, misal di desa tersebut rutin diadakannya posyandu, selain memeriksakan anak-anaknya kesempatan tersebut digunakan ibu-ibu untuk mengkonsultasikan kesehatan reproduksinya.

Berdasarkan analisa univariat tingkat pengetahuan sebagai berikut : nilai mean sebesar 13,80 menunjukkan nilai rata-rata tingkat pengetahuan responden cukup tinggi. Median 14,50, menunjukkan nilai tengah tingkat pengetahuan responden tinggi. Modus didapatkan hasil 16, menunjukkan bahwa tingkat pengetahuan tentang kanker serviks pada ibu-ibu yang paling banyak muncul pada kategori tinggi. Dari hasil tabel
2. dapat dicermati bahwa persentase motivasi responden pada kategori tinggi adalah $67,5 \%$, untuk motivasi kategori sedang $32,5 \%$, motivasi untuk kategori rendah adalah $0 \%$. Hal ini membuktikan bahwa motivasi ibu-ibu melakukan pemeriksaan Pap Smear di desa tersebut tergolong tinggi. Secara umum, motivasi artinya mendorong untuk berbuat atau beraksi. (Sunaryo, 2004) Setelah seseorang mengetahui stimulus atau objek kesehatan, kemudian mengadakan penilaian atau pendapat terhadap apa yang diketahui, proses selanjutnya diharapkan ia akan melaksanakan atau mempraktekkan apa yang diketahui atau disikapinya (dinilai baik). Indikator praktek kesehatan ini juga mencakup hal-hal tersebut, yakni tindakan sehubungan dengan penyakit, tindakan pemeliharaan dan peningkatan kesehatan lingkungan. (Fitriani, 2011)

Mayoritas motivasi responden yang tinggi adalah $67,5 \%$, secara teori hal ini membuktikan bahwa ibu-ibu di desa tersebut memahami tentang kesehatan reproduksinya dan mempunyai dorongan untuk selalu memelihara dan meningkatkan kesehatan, hal ini dibuktikan dengan adanya posyandu yang ditujukan pada balita satu bulan sekali di balai desa mereka manfaatkan kesempatan tersebut untuk konsultasi masalah kesehatan reproduksi. Berdasarkan analisa univariat motivasi sebagai berikut : nilai mean sebesar 7,73 menunjukkan nilai rata-rata motivasi responden cukup tinggi. Median sebesar 8,00, hal ini menunjukkan nilai tengah motivasi responden tinggi. Modus 9, menunjukkan bahwa motivasi melakukan pemeriksaan Pap Smear pada ibu-ibu di desa tersebut yang paling banyak muncul pada kategori tinggi. 
Di dalam proses pembentukan dan perubahan perilaku dipengaruhi oleh beberapa faktor yang berasal dari dalam diri individu itu sendiri, antara lain: susunan saraf pusat, persepsi, motivasi, emosi, dan belajar. Susunan saraf pusat memegang peranan penting dalam perilaku manusia, karena perilaku merupakan sebuah bentuk perpindahan dari rangsang yang masuk ke rangsang yang dihasilkan. Perubahan-perubahan perilaku dalam diri seseorang dapat diketahui melalui persepsi. Persepsi adalah pengalaman yang dihasilkan melalui indera penglihatan, pendengaran, penciuman. Aspek psikologis yang mempengaruhi emosi berhubungan erat dengan keadaan jasmani. Dalam proses pencapaian kedewasaan pada manusia semua aspek yang berhubungan dengan keturunan dan emosi akan berkembang sesuai dengan hukum perkembangan. Oleh karena itu, perilaku yang timbul karena emosi merupakan perilaku bawaan. Sedangkan belajar diartikan sebagai suatu perubahan perilaku yang dihasilkan dari praktik-praktik dalam lingkungan kehidupan. Dari uraian tersebut dapat disimpulkan bahwa perilaku terbentuk melalui suatu proses tertentu, dan berlangsung dalam interaksi manusia dengan lingkungannya.

Faktor-faktor yang memegang peranan di dalam pembentukan perilaku dapat dibedakan menjadi dua, yakni: faktor intern dan ekstern. Faktor intern berupa kecerdasan, persepsi, motivasi, minat, emosi, dan sebagainya untuk mengolah pengaruh-pengaruh dari luar. Sedangkan faktor ekstern meliputi: objek, orang, kelompok, dan hasilhasil kebudayaan yang dijadikan sasaran dalam mewujudkan bentuk perilakunya. Kedua faktor tersebut akan dapat terpadu menjadi perilaku yang selaras dengan lingkungannya apabila perilaku yang terbentuk dapat diterima oleh lingkungannya, dan dapat diterima oleh individu yang bersangkutan. (Notoatmodjo, 2007)

Dalam penelitian ini didapatkan skor rata-rata untuk nilai rata-rata motivasi adalah 7,725 dengan nilai tertinggi 10,00, hal ini menunjukkan bahwa motivasi ibu rumah tangga di desa tersebut tinggi. Pada penelitian ini membuktikan bahwa ibu-ibu di desa tersebut mengetahui betapa pentingnya kesehatan reproduksi, khususnya dampak bahaya kanker serviks sehingga menumbuhkan keinginan untuk selalu menjaga kesehatan khususnya organ kewanitaannya dengan memiliki motivasi yang tinggi melakukan pemeriksaan Pap Smear, mengingat bahwa kanker serviks tidak diketahui tanda-tandanya di awal stadium kecuali pada stadium 3 keatas. Hal ini dibuktikan dengan mereka selalu mencari informasi dan menanyakan berapa biaya yang harus dikeluarkan untuk melakukan pemeriksaan Pap Smear dan dimanakah pemeriksaan tersebut dapat dilakukan. Dari hasil uji statistik dengan Chi-Square program SPSS versi 18 dengan $\alpha=$ $5 \%(0,05)$ diperoleh $p$ sebesar 0,004 sehingga nilai $p<0,05$, sehingga dapat ditarik kesimpulan bahwa ada hubungan antara tingkat pengetahuan dengan motivasi melakukan pemeriksaan Pap Smear Di Desa Gulunan Sidokerto Kecamatan Plupuh Kabupaten Sragen.

Berdasarkan tabel 3. maka diperoleh data bahwa responden yang mempunyai tingkat pengetahuan tinggi sebanyak 4 orang memiliki motivasi sedang dan 21 orang memiliki motivasi tinggi dalam pemeriksaan Pap Smear, untuk tingkat pengetahuan sedang sebanyak 6 orang memiliki motivasi sedang dan 6 orang memiliki motivasi tinggi dalam pemeriksaan Pap Smear, sedangkan yang 
memiliki tingkat pengetahuan rendah sebanyak 3 orang memiliki motivasi sedang dan tidak ada yang memiliki motivasi tinggi dalam pemeriksaan Pap Smear.

Dari hal tersebut diperoleh kesimpulan bahwa ibu-ibu di Desa Gulunan Sidokerto lebih banyak memiliki tingkat pengetahuan tinggi dengan motivasi yang tinggi untuk melakukan pemeriksaan Pap Smear yaitu sebanyak 21 orang (84\%). Dengan demikian tingkat pengetahuan tinggi yang dimiliki responden dapat diartikan bahwa responden memahami dan mengaplikasikan tingkat pengetahuan yang diperoleh, hal ini sesuai pendapat Notoatmodjo (2007) pada tingkatan kognitif 2 dan 3 , yaitu bahwa responden memiliki kemampuan untuk menjelaskan secara benar kepada obyek yang diketahui dan dapat menginterpretasikan materi itu secara benar serta munculnya kemampuan untuk menggunakan materi yang telah dipelajari pada situasi atau kondisi real. Sedangkan dari hasil motivasi untuk melakukan pemeriksaan Pap Smear pada responden cukup tinggi pula, artinya bahwa ibu-ibu yang memiliki tingkat pengetahuan tinggi memiliki motivasi dengan menanamkan kesadaran dalam dirinya sehingga memiliki motivasi yang tinggi untuk melakukan pemeriksaan Pap Smear.

Hal ini sesuai dengan cara-cara memotivasi yang dikemukakan oleh Sunaryo (2007), memotivasi dengan identifikasi yaitu cara motivasi dengan cara menanamkan kesadaran sehingga individu berbuat sesuatu karena adanya keinginan yang timbul dalam dirinya sendiri dalam mencapai sesuatu. Hal ini selaras dengan hasil penelitian yang telah dilakukan oleh Fauziah pada tahun 2011 yang meneliti hubungan antara tingkat pengetahuan, sikap dan perilaku petugas kesehatan dalam melakukan deteksi dini kanker serviks pada pusat pelayanan primer di lima wilayah DKI Jakarta, dengan hasil terdapat korelasi lemah antara pengetahuan dan perilaku pada kelompok bidan $(r=0,241, p<0,05)$. Sebagian besar responden mengetahui IVA dan kegunaannya. Bidan merupakan petugas kesehatan yang sering mengerjakan Pap Smear maupun IVA.

\section{DAFTAR PUSTAKA}

Aminati, Dini. Cara Bijak Menghadapi dan Mencegah Kanker Leher Rahim (Serviks). Yogyakarta: Brilliant Books, 2013.

Andrijono. HPV, Jurnal Farmasi \& Kedokteran Ethical Digest. Jakarta: Etika Media Utama, 2006.

Fajar, Ibnu, et al. Statistika Untuk Praktisi Kesehatan. Yogyakarta: Graha IImu, 2009.

Fitriani, Sinta. Promosi Kesehatan. Yogyakarta: Graha IImu, 2011.

Hidayat, A. Aziz Alimul. Riset Keperawatan dan Teknik Penulisan IImiah. Edisi II. Jakarta: Salemba Medika, 2008.

Metode Penelitian

Keperawatan dan Teknik Analisa Data. Jakarta: Salemba Medika, 2009.

Mardiana, Lina. Kanker pada Wanita: Pencegahan dan Pengobatan dengan Tanaman Obat. Jakarta: Penebar Swadaya, 2004. 
McCormick, Colleen dan Robert L. Giuntoli. Panduan Untuk Penderita Kanker Serviks. Alih bahasa Yuan Acitra. Jakarta: PT Indeks, 2011.

Notoatmodjo, Soekidjo. Promosi Kesehatan dan IImu Perilaku. Jakarta: Rineka Cipta, 2007.

Kesehatan Masyarakat IImu dan Seni. Jakarta : Rineka Cipta, 2011.

Nurchasanah. Ensiklopedi Kesehatan Wanita. Yogyakarta: Sendangadi Mlati, 2009.

Purnomo, Heru. Pencegahan \& Pengobatan Penyakit yang Paling Mematikan Hipertensi, Diabetes, Stroke, Kanker Payudara, Kanker Rahim, Kanker Serviks. Yogyakarta: Buana Pustaka, 2009.

Siswadi, Yakobus. Klien Gangguan Sistem Reproduksi dan Seksualitas. Jakarta: EGC, 2007.
Sobur, Alex. Psikologi Umum Dalam Lintas Sejarah. Bandung: Pustaka Setia, 2003.

Sunaryo. Psikologi Untuk Keperawatan. Jakarta: EGC, 2004.

Suyanto. Metodologi dan Aplikasi Penelitian Keperawatan. Yogyakarta: Nuha Medika, 2011.

Yatim, Faisal. Penyakit Kandungan. Myoma, kanker rahim/leher rahim dan indung telur, kista, serta gangguan lainnya. Jakarta: Pustaka Populer Obor, 2005. Dosen AKPER Panti Kosala Surakarta

2 Dosen AKPER Panti Kosala Surakarta

3 Mahasiswa AKPER Panti Kosala Surakarta 